\title{
Transatlantica
}

Revue d'études américaines. American Studies Journal

\section{In, Out, and Beyond: Dislocation, Contamination and the Redemptive Power of Womanhood in California, In-doors and Out by Eliza W. Farnham,} 1856

\section{Claire Sorin}

\section{OpenEdition}

\section{Journals}

\section{Electronic version}

URL: https://journals.openedition.org/transatlantica/12474

DOI: 10.4000/transatlantica.12474

ISSN: $1765-2766$

Publisher

Association française d'Etudes Américaines (AFEA)

\section{Electronic reference}

Claire Sorin, "In, Out, and Beyond: Dislocation, Contamination and the Redemptive Power of

Womanhood in California, In-doors and Out by Eliza W. Farnham, 1856", Transatlantica [Online], 1 | 2018, Online since 12 September 2019, connection on 04 February 2023. URL: http://

journals.openedition.org/transatlantica/12474 ; DOI: https://doi.org/10.4000/transatlantica.12474

This text was automatically generated on 4 February 2023

\section{cc) (†) $\odot$}

Creative Commons - Attribution-NonCommercial-NoDerivatives 4.0 International - CC BY-NC-ND 4.0 https://creativecommons.org/licenses/by-nc-nd/4.0/ 


\title{
In, Out, and Beyond: Dislocation, Contamination and the Redemptive Power of Womanhood in California, In-doors and Out by Eliza W. Farnham, 1856
}

\author{
Claire Sorin
}

1 In 1856, the New York-based Dix, Edwards \& Co. published a book on California which received many favorable reviews, both in the eastern cities and on the newly-settled western coast. ${ }^{1}$ In January 1857, the Hutchings California Magazine recommended California In-doors and Out; or, How we Farm, Mine, and Live generally in the Golden State for its style and its illuminating treatment of a wide array of subjects:

The volume before us is descriptive of adventure, climate, scenery, soil, population and production, mining, farming, grape growing, gardening, milling, ranching and dreaming-of men and women, their education, pursuits, social habits, and condition, of what they have been, are or can be. In fact, of almost everything that is interesting in, and to Californians, from digging gold to raising calves; not omitting some suggestions of improvement to men and women. It is an interesting book, fluently and pleasingly written and we commend it to our readers. It is, moreover, the first book that has been written in, or concerning California, by a lady. ${ }^{2}$

This "lady" was no anonymous pioneer. Although her name may no longer sound familiar today, Eliza W. Farnham was a popular writer as well as a celebrated and controversial reformer in the nineteenth century. By the late 1840s, she was known as the author of a book on early Illinois and the bold matron of Sing Sing prison, where she had introduced original reforms based on phrenology. ${ }^{3}$ After the death of her husband Thomas Farnham, she decided to migrate to California, where Thomas had bought land. ${ }^{4}$ In 1849, the year of the Gold Rush, Eliza sailed from New York to San Francisco via Cape Horn, with a one-month forced stay at Valparaiso, where the captain 
of the ship, whom she had antagonized, left her stranded, sailing off with her two sons, one of whom was severely handicapped. ${ }^{5}$ Once in San Francisco, Eliza Farnham headed for Santa Cruz, where she struggled to set up a farm. In 1852, she remarried and had a daughter but her baby died in 1855 , shortly after her disabled son had passed away. Eventually, she divorced her abusive and alcoholic husband in 1856. While Farnham's tragic experience of loss, grief, domestic strife and financial problems was not unique, her public career was notable as she became a respected lecturer and asylum reformer in California in the second half of the 1850 s. $^{6}$

3 In the preface to California In-doors and Out, written in 1856, Eliza notes that her personal experience was "not more novel than that of scores of my sex who emigrated both before and after 1848" and she thanks God for having been spared the trials of physical suffering and utter destitution (iv). This humble, religious stance characterizing the whole preface-and indeed many female-authored writings of the time-also aims to suspend disbelief in the reader, for her tale, warns Farnham, contains "strange developments" and "grotesque features" (v). Although not unique, the extraordinary narrative of her personal story promises to be "as tamely stated as truth will permit" (iv).

4 It seems, however, that Farnham's professed love of truth did not extend to the most painful events of her private life as she writes nothing about the failure of her farming experiment, her unhappy remarriage, the loss of her children, or her divorce. This silence is all the more striking as the first chapters of the book are openly autobiographical. Emptied of its subjective narrative source, the second half of the volume adopts a journalistic style which strongly contrasts with the vivid, often humorous tone of the previous pages. In the process of writing, which began in the early 1850 s and ended in 1856, Eliza seems to have dis-located herself, both on a personal and discursive level.

5 The notion of dislocation-both as process of displacement and state of disruptionaptly describes the dialectics shaping the flesh and skeleton of the narrative. Indeed, as a story of dis-location and of attempted re-location, Eliza Farnham's book revisits gendered space and spatial boundaries, picturing, as its title indicates, indoors and outdoors life, but exploring above all the porous nature of these "doors" and the shifting frontiers between the "in" and the "out," which not only stand for domestic and public spheres but also for the spiritual and the material, the self and nature, nation and world. California In-doors and Out is deeply permeated with contemporary discourses of Manifest Destiny and domestic ideology which Farnham merges into a form of "Manifest Domesticity" (Kaplan). The present essay proposes to analyze Farnham's work as a reconfiguration of the separate spheres model, highlighting the connections between gendered spaces and issues of race, nation and empire. ${ }^{7}$

6 It is crucial to point out that in the 1850s, Farnham's fairly conventional belief in the Home as a vector of social purity was evolving toward a more radical vision of woman's superiority, which her subsequent work fully expounded. ${ }^{8}$ Before her emigration to California-and partly with a view to financing it-she tried to set up a project inciting poor and virtuous eastern women to move west and civilize "that distant and homeless land" (Levy, 2004 35). ${ }^{9}$ Her project failed but her book contains an appeal to women readers, urging them to come and carry out their redemptive mission. Farnham's narrative teems with images of contamination and promises of redemption anchored in California's unique potential for freedom and equality, and in a firm doctrine of female 
purity. The feminization of California, then, is presented as a prerequisite for its full democratization.

\section{"California is altogether anomalous": Spatial and Textual Dislocation}

7 Eliza Farnham's first glimpse of San Francisco, from the ship, is marked by a blurring of familiar spatial landmarks:

[...] we dropped anchor somewhere off North Beach, on the tenth evening, after it was too late to see anything, but two or three straggling lights shining dull through the fog that never cleared, and the rain that never ceased pouring [...] the next day [...] we went ashore almost immediately, if that could properly be called shore where the falling flood filled the atmosphere so, that floundering along with a strong man at each elbow, we seemed to be almost submerged, and felt thankful for so small a favor as having the upper portions of our persons bathed in a medium somewhat purer than that below. (Farnham, 1856 21-22)

In a scene reminiscent of the deluge, Eliza is introduced into this new land through a somewhat grotesque baptism that leaves her neither pure nor whole. Drenched and half-drowned, she immediately becomes upon landing an object of curiosity, for white women were so rare at the time that they were "uncomfortably stared at." ${ }^{10}$ Forming "little islands" in the streets, men left the gaming houses and the bar rooms to gaze at her (22-23).

8 The confusion between water and earth, the undefined contours of the shore and the moral impurity of San Francisco all mark a deep contrast with the well-ordered, bright, Eden-like landscape of her Santa Cruz farm where, upon arrival, she experiences a genuine aesthetic and mystical shock. Becoming the gazer this time, she depicts a scene whose epiphanic function is linked to the perfect architecture of the surrounding space:

I look at a picture so filled with repose and beauty, that while I gaze, the hateful stir of the world seems to die out of the universe, [...] On either hand, at a short distance from the stream, rise hills, now beautifully rounded, now more abrupt and stern, but all clothed with richest herbage, [...] Just back of the house these hills approach each other so nearly, that what is a broad vale becomes a deep ravine, with wooded banks, upon which a dozen tall redwoods tower above their neighbors, and seem, to my wondering eyes, to be penetrating the very clouds. In front, the hills open generously [...] Beyond this, I gaze upon the sparkling waters of the great bay, whose surrounding coast is diversified by hill and plain, cloud and sunshine, so exquisitely, that I deem it a fairy scene, [...] I wonder, while beholding it, that religious and devout thankfulness to God does not continually ascend from the hearts of those who dwell in so fair a portion of his creation. (Farnham, 1856 45-46)

Those two contrasting scenes of fog and sunshine, flood and rebirth, humiliation and revelation, somehow encapsulate the gist of Eliza Farnham's migration experience as well as that of California itself. Indeed, in this land of unceasing fluctuations, of paradox and distortion (Farnham 1856 367), norms are constantly disrupted. This is first visible in the gigantic size of nature-the enormous size of the horned cattle, the impressive height of the wheat and the immensity of the trees-that Farnham details for the eastern reader and that she ascribes to "the energy of California soil" (202-203). California itself is personified as a "young giant but half conscious of its own power" (21) and life in this part of the globe, concludes Farnham, is "altogether anomalous" (28). 
"out" that the swift-changing nineteenth-century American society carefully erected. The theory of "separate spheres," the ideal of "true womanhood" and the "cult of domesticity," all dear to Victorian culture, partook of an attempt to categorize and stabilize the social and economic transformations, as well as the gender relations of the expanding nation. In theory at least, the home was exalted as a walled sanctuary protecting man and woman from the hustle and bustle of the world.

10

But in California, the home as physical and moral shelter is either absent, dirty, or dilapidated. The typical "rancho style" is described as "a dark, dirty, adobe house, windowless, swarming with fleas, the ground in all directions strewn with bullock's heads, horns, and hides, and guarded by an immense troops of worthless dogs" (Farnham 1856 181). When Eliza arrived at her own farm, she found a "casa [...] made of slabs which were originally placed upright, but which have departed sadly from the perpendicular in every direction" (42-43). After discovering the "fairy scene" mentioned above, she describes her coming back to the broken house. Sitting in the ashes, she contemplated her "in-door world" and mentally started to construct a home: "In my meditations, I inverted the black walls, turned them inside out, laid an ideal floor, erected imaginary closets set apart corners for bedrooms" (48).

11 In reality, the reconstruction of the house was much more painstaking and imperfect. First, she had to sleep in a tent and live in a "half nomadic state"; then, in passages fraught with humor, Farnham depicts her attempts to divide the space of the casa into apartments partitioned by curtains which, like the thin outer walls, failed to provide proper privacy (67). Eventually, Eliza's home was reduced to a stoveless shelter housing a non-nuclear family. ${ }^{11}$ Only later in the narrative was a brand-new house erected which, at least in imagination, recreated the cozy, genteel space of Victorian homes, neatly divided into sleeping chambers, bathroom, library, parlor and dining room (104-105, 169).

12 Yet, this recreated home does not become the focus of Eliza's domestic activities, for the book mainly stages the narrator/character outdoors, engaged in all sorts of physical tasks including plowing, gardening, planting potatoes and building the roof of the house. Farnham readily depicts herself as a house builder rather than a housekeeper, a reversal of traditional gender roles that she attributes to California's peculiar character: "it is no more extraordinary for a woman [here] to plough and hoe with her own hands than for men to do all their household labor" (28).

Her job as carpenter (a male but holy occupation) enabled her to discard the long traditional dress and don the bloomer costume, which she found so comfortable that she eventually decided not to change dresses even when male visitors came (133). ${ }^{12}$ While this victory over bodily constraints and genteel expectations signals the greater degree of women's emancipation in the west, it should be noticed that Farnham did not openly militate for women's rights, for she believed-like other contemporary promoters of the theory of separate spheres-that a woman's nature was essentially spiritual and domestic. ${ }^{13}$ When her friend Georgiana Bruce Kirby, a fervent supporter of the newly launched women's rights movement, noted that her daily life and activities contradicted her principles, Farnham justified the paradox by claiming that "necessity prescribed [her] practice and only reason, taste and conscience [her] theory" (173).

Transatlantica, 1 | 2018 
The pressing demands of her new environment occupy a central place in the first half of the book, which reads like a lively, epic tale of war against all sorts of enemies in the shape of fleas, weeds, rain, grasshoppers, and unreliable employees. This "continual external struggle" has mixed consequences on her life and on the frame of her narrative: at one point, Farnham notes that her spirit is so overwhelmed by material concern that despair and social isolation threatened to pervert her soul and her usual wonder at the "visible throne of God" (152). In a land where human society barely existed, the private space of her secluded home became a prison:

Shut up in my narrow house, with the interests and sympathies which had been wont to embrace classes, communities, humanity, chilled and driven back upon myself; unable to approach the social life about me in the way of co-operation or enjoyment, or individuals in the relation of serving or aiding [...] I was, most of all unhappy in finding myself circumscribed in all action to my small family circle and my private interests. (Farnham, 1856 154-155)

This passage, which sheds light on the intricate intersections between the public and the private, redefines the notion of home. As an eastern reformer and a defender of women's domestic nature, Eliza Farnham had learned to expand the walls of her house so that it could transcend her own "small family circle." ${ }^{14}$ As is made clear here, the ideal home was not supposed to be an insulated haven but a private locus connected to and, through woman's loving and selfless power, devoted to the outside world ("classes, communities, humanity"). In the same way as a world with no homes was likely to degenerate into a masculine jungle, a home cut off from the public sphere could shrink into a prison cell. Farnham laments the loneliness and the lack of social fabric and purpose which made educated and well-meaning females like herself feel "out of place" (155); she concludes this despondent chapter by warning that "none but the pure and strong-hearted of my sex should come alone to this land" (157). It seems, at this point in the narrative, that her social and spiritual identities can neither exist "in" nor "out" and that her sense of self is literally dislocated.

Farnham was redeemed by the coming of a female friend, with whom she shared the kind of intense and long-lasting friendship bonding nineteenth-century women. ${ }^{15}$ Georgiana Bruce Kirby joined her in 1850, worked by her side on the farm and cheered her spirits. Reflecting on her trials in a subsequent introspective passage, Farnham concludes that "each struggle had contributed to my womanhood. Each had helped on my interior life. Are not the internal experiences of like natures like, under all external circumstances, however various? Do not the truly good truly advance in their own souls?" (224).

16 This passage offers the last insight into Eliza's interior life, for from chapter 27 to the end (chapter 40), the narrative abruptly changes in focus, tone, rhythm, and characterization. While the first part of the book reads like an entertaining and informative novel, intertwining the adventures of Farnham's private life with the main features of California's history, the second half of the volume is a rather terse, somewhat impersonal account of external characteristics. Thus, the mixed population, the evolution of San Francisco, the widespread corruption in morals and politics, and gold mining are documented in a series of shorter chapters where the subjective narrator is replaced by the voice of a witness, reporter or travel guide. This trend climaxes in the last two sections composed of an appendix and a supplementary chapter which detail the 1856 activities of the Vigilance Committee and relate the story 
of a dreadful emigration experience in 1846 known as the "Donner Party." ${ }^{16}$ The reader thus perceives a dissonance in the narrative that Farnham never justifies.

Increasingly, the author's personal voice dissolves into the widely used pronoun "we," which is inscribed in the very title of the book and has fluctuating referents-her own family group, the Californians with whom she identified, or the "old world" to which, as a "civilized" and educated lady, she still belonged. The recurrence of the first-person plural actually operates like an inclusive and exclusive force that creates an illusion of cohesion while keeping the contours of the narrating subject undefined. Both in and out of the narrative, Farnham's voice becomes disembodied, more openly didactic and moralizing, and eventually prophetic.

\section{Contamination and the Redemptive Power of Womanhood}

18 In the latter part of the book, Eliza Farnham is concerned about the mechanisms of contamination, purification and redemption shaping California's budding society. While the bountiful nature is conceived as a gift of God, the cities and the mining towns are depicted as hellish places where language, manners, and social relations have degenerated into swearing, violence and selfish individualism (Farnham, 1856 271). Farnham noted that the gaming houses, most numerous in San Francisco, also prevailed throughout the country and that the "inland towns were equally infested" (307). Oaths, she laments, "crowded into the commonest conversation" and even women were not immune to impure language (297). Bar rooms thronged and drunkenness was a rampant vice that contaminated even the children (357).

The main culprit for this degenerate society, Farnham claims, is gold, or rather the blind quest for it which, "once tasted, like the fabled leaf, causes forgetfulness of old ties [...] and does not create new ones" (251). While she admits that the Gold Rush marks a revolution in history which will ultimately amount to progress (356), and that gold-seeking fosters the "republican sentiment" by enabling any poor and lucky hardworking man to get rich, she dwells on the immediate negative consequences of the craze for gold (353).

20 The first one is that it attracts, in the reported words of a white Californian, "all types of rascality" (332). Farnham targets in particular the "foul population" from Australia, those "carrion birds," whose "pestilent presence" invaded the land (332). Chinese emigration is curiously absent from her report, which essentially focuses on the different types of European and American migrants in ways that both qualify and reinforce stereotypes. Farnham writes that "the Jew [...] does honor to his name here. He eschews old clothes, and rarely if ever, so far as my observation entitles me to speak, attempts to get a greater advantage in trade than his neighbors" (264). The New England Yankee is censored for his speculative mind, his business talents, and his dislike of hard manual labor; brushing aside the Puritan work ethic, Farnham declares that "the American is not a working animal like the Swiss, the German, the Irishman or the Englishman" and she ironically adds that the Puritan colonial venture might have failed in the mild and sensuous climate of California (265). ${ }^{17}$

21 The other consequence of the Gold Rush concerns the widespread corruption plaguing politics and justice, which the narrative documents with many anecdotes of bribed 
politicians, immoral judges, swindled elections, and unpunished criminals. Farnham notes that "in the California of ' 49 and ' 50 [...] no man appeared desirous of abiding by these laws, unless the law and his pleasure were one, and the courts seemed to be little more guided by it than individuals" (93). The whole public sphere is likened to a sick body contaminated by "venality" which "cannot better consist with true civil and political greatness, than can organic disease with perfect animal development. It is the gangrene ever surely eating its way to the sources of vitality" (379). Most importantly, Farnham laments "the decline in personal, social and civil morality" which tests and threatens the "Saxon spirit": "The respect one feels for the noblest race on earth, does not mitigate the pain of witnessing its degradation in the same fields where inferior peoples have fallen" (306). In the narrative, the "inferior peoples" mainly include the Native Americans (referred to as "Indians") and the conquered Mexicans (labeled "Spanish" or "old Californians"). Farnham treats them with mixed feelings of contempt and pity, highlighting their simple-heartedness, laziness, lack of ambition as well as cleanliness $(131,181,182)$. She also notes that in the "absence of that grand characteristic of enlightened Christianity-respect for woman"-wives, sisters and mothers are in "the position of a humanely-treated slave" (183-184).

Farnham's praise of Anglo-Saxon racial and moral superiority reflects her vibrant faith in Manifest Destiny. As she sees and foresees redemption for California, her writing becomes permeated with a form of visionary optimism which gives way to flights of lyrical prose strongly reminiscent of John O Sullivan's glorification of America: ${ }^{18}$

America is young and strong; [...] Her civilization, springing from Saxon energy, Protestant Christianity, and social, political and religious liberty, has in it elements of durability never before combined. (331)

California is the world's nursery of freedom. The centuries [...] have witnessed no event so significant to the nations as its development under a free government. It marks an era to which, in future years, the new men of nations grown hoary in despotism, will point as the time when the masses began to gather the earth's treasures and make them their own. The lessons in political and religious freedom learned here will be remembered and repeated beneath the palm trees of India-in the tea-fields of China-among the frozen snows of Russia-in the saloons of the proudest cities of Europe, where dotard monarchy yet hugs his shivering members together-[...] What hopes are awakening in these years! [...] What persistency in man toward a high destiny! [...] The march will be onward with triumph into the ages. (327-329)

In this utopia exalting America's exceptionalism and California's potential for universal regeneration, California is portrayed as the "theatre of first test" for absolute liberty. Thus, the young state is meant to carry out the original republican experiment to its extreme logic of democracy: "If America is republican elsewhere, here she will be democratic" (277). Farnham already saw many signs of this new era in the tangible progress that she had noticed over the seven years she spent in California. Thus, she noted the diminution of gambling houses, the decline in alcohol consumption, the development of social and educational institutions, and mostly, she felt confident that, once the gold fever had died down, the fertile lands of California would materialize the Jeffersonian dream of a great agrarian republic peopled by virtuous farmers. It is not by chance that the passages describing farming far outnumber those that she somewhat reluctantly devotes to gold mining. She encouraged her readers to till the land instead of digging gold, predicting that this would increase health and virtue and "elevate [California] to the level of her elder sisters" (31). 
Another sign of social and moral purification is commented upon at great length in the last section of the book devoted to the Vigilance Committee, an association of San Francisco citizens created in response to the widespread crime and corruption. Its wellorganized members judged and executed criminals, patrolled the city to protect life and property, and in 1856, they issued a document inspired by the Declaration of Independence which asserted the people's right to self-government and hinted at revolution. Farnham relates the conflict that opposed the Vigilance Committee to the governor of California and she gives her undivided support to the action of the Committee, lauding the nobility, courage and self-restraint of its members, whom she implicitly compares to the Founding Fathers of California. Rejoicing that "the country is redeemed from the worst of all despotisms-a despotism of ruffians (505), she thanks them for having taken indispensable "steps of purification" (499) in San Francisco and given examples of republicanism served by "true manhood" (507). ${ }^{19}$

While the courage, honesty and "moral power" (501) of "true manhood" are presented as necessary ingredients for the salvation of California, the book is ultimately a tribute and a call to the redemptive power of "true womanhood." The scarcity of women, the impossibility to set up families-especially in the mining towns-the presence of prostitutes and the constant and unjust sexual suspicion bearing on all women are put forth by Farnham as the most serious obstacles to the purification of the social sphere. Through several anecdotes, in particular in the chapter narrating the emigration of the Donner Party that stages the heroic selflessness of a mother ${ }^{20}$-and implicitly through her own story-the author glorifies womanhood. Her praise of female courage, of the almost miraculous power of motherly love, of women's self-sacrifice and unrivaled capacity for survival elevates woman to the level of Christ. The book is finally an invitation to martyrdom:

Come to the country which is the home of those you are bound to adhere to and save, [...] I say to my countrywomen that if they have the natures which can pass unscathed through the furnace seven times heated, every sentiment of duty binds them to follow here, [...] one suffers with so much more firmness when one feels that good flows from it-though it be to the antipodes. [...] We see the fruits of the martyrdoms that have been. We feel the pains only of our own. (301-305)

Farnham thus issues a call to the "Angel in the House," ${ }^{21}$ urging her to leave her home and found a purer state. The book ends with a vision of redeemed California reminiscent of her initial mystical experience upon discovering the Santa Cruz landscape:

When society shall have struck its roots into Californian soil [...] [t]hen the benign summer heavens will smile upon hearts tranquil enough to expand beneath them into charity and love-free enough to be penetrated by the exquisite harmony of the material world-then the glorious hills and teeming vales will be dotted with homes where plenty reigns [...] A country so clothed with majesty [...] must have a hopeful destiny. (377-378)

This civilized, christianized, feminized, version of the picture, which blends the accents of Manifest Destiny with the virtues of domesticity, provides a good illustration of "Manifest Domesticity," i.e. a combined rhetoric of national expansion and domestic ideology that "turns imperial conquest into spiritual regeneration to efface internal conflict or external resistance in visions of geopolitical domination as global harmony" (Kaplan 190). 


\section{Conclusion}

California In-doors and Out emerges as a non-uniform narrative offering American readers the vision of a harmonized civilization based on the contemporary assumptions of Anglo-Saxon superiority and female innate virtue. In this utopian projection where the Native Americans and the conquered Mexicans are hardly visible, the "other" to be conquered is human (mainly male) moral impurity. As Farnham writes: "The present is a war, not between parties or persons, but between the principles of good and evil" $(1856 \mathrm{v}$-vi). To some extent, this moral war reshapes-and is reshaped by-the tensions between the "in" and the "out," which take on multiple forms and sometimes contradictory values: California is both a home and a strange land, the domestic space a claustrophobic and regenerative haven, the public sphere gangrened and destined to become the vector of universal democracy. Also, porosity between indoor and outdoor spaces may be infectious or healing, constructive or destructive. Ultimately, however, Farnham's grand scheme is to dissolve the frontiers between the external and the internal, and attain a stage when the soul, no longer absorbed by physical concerns, can be, as is said in the above-quoted extract, "penetrated by the exquisite harmony of the material world."

Farnham's apocalyptic vision of a new heaven and a new earth is coupled with a final prediction that, once the dark shadow of slavery has been removed, California and the other states will form a great domesticated nation of freedom. Looking beyond the increasing sectional tensions plaguing the country, she inscribed on the book's last page: "Let the talking wires span free soil from the Atlantic to the Pacific, and let free labor, with its enterprise, progress, and intelligence, possess and build up Kansas and Nebraska, through which California will ultimately be connected, by railroad, with the East and in a few years, she will be the garden of the Union" (507). Interestingly, the final comparison of California to a garden, which echoes the image of the "nursery" of freedom, not only hints at the state's bountiful and tamed nature; in the House/Nation metaphorical configuration, it also identifies California to a hybrid and fecund space located both in and out of the Union. It seems that Farnham's gender theory and female experience, professedly anchored in the separate spheres model, actually found their deepest roots in such a hybrid and fecund space, generated by the blurred and moving frontiers of the domestic empire.

\section{BIBLIOGRAPHY}

BAYM, Nina. Women Writers of the American West. Urbana: University of Illinois Press, 2012.

CHURCHILL, Charles B. "Thomas Jefferson Farnham: an Exponent of American Empire in Mexican California.” The Pacific Historical Review, vol. 60, no. 4, 1991, p. 517-537.

COTT, Nancy F. The Bonds of Womanhood: “Woman's Sphere" in New England, 1780-1835. New Haven: Yale University Press, 1977. 
DAVID Lewis, W. "Farnham, Eliza Wood Burhans." Notable American Women, vol. 1. Eds. Edward T. James, Janet Wilson James, Paul S. Boyer. Cambridge, MA: Belknap Press of Harvard University Press, 1971, p. 598-600.

DAVIDSON, Cathy N. and Jessamyn HATCHER. "Introduction.” No More Separate Spheres! Eds. Cathy N. Davidson and Jessamyn Hatcher. Durham: Duke University Press, 2002, p. 7-26.

EPSTEIN, Barbara L. The Politics of Domesticity: Women, Evangelism, and Temperance in NineteenthCentury America. New York: Wesleyan University Press, 1981.

FARNHAM, Eliza. California, In-doors and Out; or, How we Farm, Mine and Live generally in the Golden State. New York: Dix, Edwards \& Co., 1856.

FARNHAM, Eliza. Life in Prairie Land. New York: Harper \& Bros., 1846.

FARNHAM, Eliza. Woman and Her Era, 2 volumes. New York: A.J. Davis \& Co., 1864.

FARNHAM, Eliza. Letter to Parke Godwin, August 11, 1855. JoAnn Levy Papers, California State Archives, Sacramento.

FARNHAM, Eliza. Letter to a friend in New York, December 30, 1849. JoAnn Levy Papers, California State Archives, Sacramento.

FISCHER, Gayle V. Pantaloons and Power, a Nineteenth-Century Dress Reform in the United States. Kent, OH: The Kent State University Press, 2001.

GINZBERG, Lori. Women and the Work of Benevolence: Morality, Politics, and Class in the NineteenthCentury United States. New Haven: Yale University Press, 1990.

HELSINGER, Elizabeth K., Robin Lauterbach SHEETS, and William VEEDER. The Woman Question, Society and Literature in Britain and America, 1837-1883, vol. 2. Chicago: University of Chicago Press, 1983.

JOHNSON, Kristin, ed. Unfortunate Emigrants: Narratives of the Donner Party. Logan, UT: Utah State University Press, 1996.

KAPLAN, Amy. "Manifest Domesticity.” 1998. No More Separate Spheres! Eds. Cathy N. Davidson and Jessamyn Hatcher. Durham: Duke University Press, 2002, p. 183-207.

KERBER, Linda K. “Separate Spheres, Women's Worlds, Woman's Place: The Rhetoric of Women's History." 1984. No More Separate Spheres! Eds. Cathy N. Davidson and Jessamyn Hatcher. Durham: Duke University Press, 2002, p. 29-65.

LEVY, JoAnn. Unsettling the West, Eliza Farnham and Georgiana Bruce Kirby in Frontier California. Berkeley: Heyday Books, 2004.

LEVY, JoAnn. They Saw the Elephant, Women in the California Gold Rush. Norman: University of Oklahoma Press, 1992.

O'SULLIVAN, John. “The Great Nation of Futurity.” The United States Democratic Review, vol. 6, no. 23, 1839, p. 426-430.

PATMORE, Coventry. The Angel in the House. 2 vols. London: John W. Parker and Son, 1854-1856.

PIEPMEIER, Alison. Out in Public: Configurations of Women's Bodies in Nineteenth-Century America. Chapel Hill: The University of North Carolina Press, 2004.

RILEY, Glenda. Inventing the American Woman, vol. 1. Wheeling, Illinois: Harlan Davidson, Inc., 1995. 
SMITH-ROSENBERG, Carroll. "The Female World of Love and Ritual: Relations between Women in Nineteenth-Century America." 1975. Disorderly Conduct: Visions of Gender in Victorian America. Carroll Smith-Rosenberg. New York: Oxford University Press, 1985, p. 53-76.

SORIN, Claire. "Anatomy of the Female Angel or Science at the Service of Woman in Woman and Her Era by Eliza Farnham." Women and Science, $17^{\text {th }}$ Century to Present: Pioneers, Activists and Protagonists. Eds. Donna Andréolle and Véronique Molinari. Newcastle upon Tyne: Cambridge Scholars Publishing, 2011, p. 55-68.

STANTON, Elizabeth Cady, Susan B. ANTHONY and Mathilda J. GAGE. History of Woman Suffrage, vol. 1, 1848-1861, 1881.

WARREN, Kim. “Separate Spheres: Analytical Persistence in United States Women's History." History Compass vol. 5, no. 1, 2007, p. 262-77. DOI: 10.1111/j.1478-0542.2006.00366.x. Accessed 15 Nov. 2016.

WELTER, Barbara. “The Cult of True Womanhood: 1820-1860." American Quarterly, vol. 18 no. 2, part. 1, 1966, p. 151-74.

WOLOCH, Nancy. Women and the American Experience. New York: Knopf, 1984.

WOODWARD, Helen Beal. The Bold Women. New York: Farrar, Straus and Young, 1953.

\section{NOTES}

1. The book was primarily but not exclusively intended for an eastern audience. Eliza Farnham asked for 300 copies of her work to be sent to California (Letter to Parke Godwin, August 11, 1855).

2. For a survey of early women's writings on California, see Baym and Levy.

3. Eliza Farnham's first book, Life in Prairie Land (1846), was an account of her years in Illinois where she joined her sister and got married in 1836. Back in her native New York State, she headed the women's division of Sing Sing prison from 1844 to 1848 and was forced to resign because the prison inspectors disapproved of her liberal methods.

4. A staunch supporter of U.S. territorial expansion, Thomas Jefferson Farnham (1804-1848) led a missionary expedition to Oregon in 1839 and lived for a while in California where he bought land in Santa Cruz. He published four books relating his travels between 1842 and 1846. For more detailed information, see Churchill.

5. Thomas Farnham and Eliza had three sons but only one reached adulthood. Eliza's hectic voyage to California is related in Levy (2004 35-39).

6. For details on women's experiences in the early phase of California's settlement, see Levy (1992). In the mid 1850s, Eliza Farnham gave a series of public lectures on spiritualism (of which she was an eager adept), philosophy, contemporary civilization and female valor. She returned to New York City in 1856 and came back to California in 1859 when she resumed public lecturing and became matron of the female department at the Stockton Insane Asylum. During the Civil War, her abolitionist convictions incited her to volunteer as a nurse at Gettysburg. She contracted tuberculosis and died in December 1864.

7. Since the 1960s, historians engaged in the rewriting of women's history have produced an impressive amount of studies focusing on the shift in gender roles and sexual ideology in nineteenth-century America. In the wake of Barbara Welter's foundational 1966 essay ("The Cult of True Womanhood"), the metaphor of separate spheres was systematically used by critics, to such an extent that its language became "vulnerable to sloppy use" (Kerber 37). Since the late twentieth century, with the rise of queer theory and black feminist criticism, the inadequacy of 
the metaphor has been pointed out by a number of literary critics and historians denouncing a middle-class white bias that excludes other women and other categories of analysis, such as "race, sexuality, class, nation, empire, affect, region and occupation" (Davidson and Hatcher 9). Post-separate spheres criticism also points at the porous boundaries of gendered spaces, stressing the need to deconstruct binaries and to "consider the spheres not as a determining force but as one discourse among many that shaped the lives of women in the nineteenth century" (Piepmeier 5). While the present essay acknowledges the porosity of spheres, it does not reject the validity of the separate spheres metaphor and considers it a "useful tool because with an understanding of intended gender boundaries, scholars will be able to continue to identify the expansion of such limits" (Warren 270).

8. Like other nineteenth-century female reformers, such as Sarah Hale and Catharine E. Beecher, Farnham promoted the domestic ideology and insisted that woman's nature was primarily fit for a domestic life. Yet, she was unique in the sense that her belief in the angelic ideal gradually developed, through the 1840s and 1850s, into a radical theory of absolute female superiority. Her 1864 master work, Woman and her Era, fully expounds her gynecocratic views, arguing that women are not only spiritually but also organically superior to men; in Farnham's utopia, Woman is described as a semi-divine creature destined to redeem the world (for more details on this aspect, see Woodward and Sorin). This essentialist approach, which heralded "a female savior leading the way to a fuller humanity and ushering in a new era of community and love," has been coined "apocalyptic feminism" (Helsinger xv). While the emerging women's rights movement preferred to stick to an egalitarian ideal, Helsinger notes that the tenets of apocalyptic feminism deeply inspired late nineteenth-century reforms seeking to "purify" society, such as temperance and the fight against political corruption (xv).

9. Farnham's initial plan meant to recruit 130 widowed or single female participants "not under twenty-five years of age, who shall bring from their clergyman, or some authority of the town where they reside, satisfactory testimonials of education, character, capacity,\&c." Each woman was also expected to pay 250 dollars (letter to Lydia Sigourney, February 22, 1849). Eventually, only 5 women were part of this expedition which Farnham was unable to organize successfully, partly because she was ill during the weeks preceding departure.

10. It is estimated that men constituted $90 \%$ of the migrants at the time of the Gold Rush. On arriving in San Francisco, Eliza Farnham wrote a friend in New York that "women are more in requisition here than gold or anything else" (letter from E. Farnham, December 30, 1849). For more details on the female population in the California Gold Rush, see Levy, 1992 xvi-xxii.

11. In the early phase of her California years, she lived with her two children, one, then two women friends and the Irishman she hired as help.

12. Popularized by Amelia Jenks Bloomer in the early 1850s, this costume was composed of a knee-length dress worn over loose trousers. Its comfortable and healthy cut enabled women to breathe and move more freely than in the long and cumbersome traditional dress. The bloomer costume reflected the concerns of the health reform movement and was adopted for a time by the early women's rights' advocates as a symbol of emancipation. Many women also wore it for practical reasons and this seems to have been the case in San Francisco. See Fischer (79-131) and Levy ( 1992 180-182).

13. While Eliza Farnham was aware of women's oppression and respected the work of the women's rights' advocates, she thought that the fight for suffrage and political equality did not suit a woman's true mission and nature. In 1858, she spoke at the National Woman's Rights Convention in New York City and exposed her views on female superiority which impressed the audience but were not welcome by the leaders of the movement (see Stanton, Anthony and Gage's History of Woman Suffrage 669).

14. As many late twentieth-century studies have shown, since the early nineteenth century, a growing number of women had gradually learned to expand their ascribed sphere of action; by 
anchoring their motives in religious and moral grounds-their legitimate domain-they could get involved in various reform movements meant to cleanse the society of its sins, be they alcohol addiction, sexual license, or slavery. Not all women got committed and only a minority became abolitionists, but the global religious atmosphere pervading the period (Second Great Awakening) vindicated the existence of such attempts at purification. For illuminating surveys of these aspects, see for instance Epstein, Riley, Woloch, Clinton, Ginzberg.

15. Carroll Smith Rosenberg's 1975 foundational essay ("The Female World of Love and Ritual") identified a specific women's culture in nineteenth-century America, marked by female bonding, spirituality and occasional homoeroticism. There is no evidence that erotic relations existed between Kirby and Farnham but their mutual emotional commitment to their friendship is obvious through the many letters they exchanged from the 1840s to the time of Eliza's death. Smith-Rosenberg's work and many subsequent others, including Nancy Cott's 1977 Bonds of Womanhood, marked a reappraisal of the separate spheres model, arguing that the women's sphere could be turned into a potentially positive force.

16. The Donner Party refers to the tragic migration of a group of 87 men, women, and children who left Illinois in 1846 and were trapped in the snows of the Sierra Nevada. Half of the group died of exposure, disease or starvation and some resorted to cannibalism. For more information on this event, see Johnson.

17. It is important to note that despite these critical views Farnham assumed that, contrary to the Spanish character, the Americans of Anglo-Saxon origins were also endowed with "unfaltering energy," "self-control," "personal courage" and "sublime patriotism" (267).

18. The journalist and editor John O'Sullivan (1813-1895), who is credited for having coined the phrase "Manifest Destiny" in his 1845 article defending the annexation of Texas, extolled its main themes as early as 1839 in "The Great Nation of Futurity" (The United States Democratic Review, volume 6, issue 23): "Yes, we are the nation of progress, of individual freedom, of universal enfranchisement [...]. We must onward to the fulfilment of our mission-to the entire development of the principle of our organization-freedom of conscience, freedom of person, freedom of trade and business pursuits, universality of freedom and equality. This is our high destiny [...]. All this will be our future history, to establish on earth the moral dignity and salvation of man [...]. For this blessed mission to the nations of the world [...] has America been chosen; and her high example shall smite unto death the tyranny of kings, hierarchs, and oligarchs [...]" (429-430).

19. Farnham devotes a "supplementary chapter" to the Vigilance Committee, induced by the 1856 conflict that was opposing the second Committee to California's political authorities. The chapter describes the activities of the first Vigilance Committee, organized in 1851, and then proceeds to analyze the unfolding crisis. It includes the complete transcription of the document addressed by the Vigilance Committee to the people of California on June 9, 1856.

20. While two-thirds of the males of the Donner party died, two-thirds of the women survived and reached California. Farnham interpreted this gap as proof that women, and mothers in particular, were endowed with a higher capacity for survival conferred by "love's divine selfabnegation" (422).

21. This phrase, which was made famous by Coventry Patmore's long narrative poem, first published in 1854, and expanded until 1862, became a catch phrase in the late nineteenth century to refer to the ideal wife and mother. It is difficult to know whether Farnham had actually read the poem, but "The Angel in the House" perfectly encapsulates her belief in the angelic nature of women primarily fit for the domestic sphere. 


\section{ABSTRACTS}

Eliza W. Farnham (1815-1864) was the first woman migrant to publish a book on California. Her 1856 account offers a unique insight into the early and essentially male phase of California's settlement, as well as a complex narrative of personal adaptation to a new environment. Its vivid and at times humorous descriptions of agrarian life, embryonic political institutions, social relations and violence, are permeated with the spirit of Manifest Destiny. Yet, the deep originality of Eliza Farnham's account lies in its gendered perspective, which combines traditional and radical views of the female sex and disrupts dialectics of public and private spheres. This partly autobiographical book blurs the frontiers between the "in" and the "out" and contains the seeds of the gynecocracy theories that the author subsequently expounded in a voluminous work aiming to demonstrate the absolute superiority of the female sex (Woman and her Era, 1864).

Eliza W. Farnham a publié en 1856 le premier ouvrage écrit depuis la Californie, et sur la Californie, par une femme. Ce récit à la fois personnel et impersonnel offre une plongée unique dans la Californie à la période de la ruée vers l'or et révèle les réactions d'une femme originaire de New York et son adaptation à un univers essentiellement masculin. Le portrait du nouvel état et de ses embryons d'institutions sociales et politiques est fortement influencé par les discours de la Destinée Manifeste. Toutefois, Eliza Farnham introduit dans son récit une perspective genrée qui combine une vision à la fois traditionnelle et radicale du sexe féminin tout en brouillant la frontière des sphères publiques et privées. Cet ouvrage partiellement autobiographique, qui reconfigure les espaces intérieurs et extérieurs, contient également les germes de la pensée gynocratique que Farnham exposera pleinement dans son œuvre maitresse Woman and her Era, publiée en 1864.

\section{INDEX}

Mots-clés: Californie, sphères publiques et privées, espace, frontières, genre, maison, nation, hybridité

Keywords: California, public and private spheres, space, frontiers, gender, house, nation, hybridity

\section{AUTHOR}

CLAIRE SORIN

Aix Marseille Université, LERMA, Aix-en-Provence, clairesorin@hotmail.com 